\title{
Beyond the three-component model of organizational commitment
}

Citation for published version (APA):

Solinger, O. N., van Olffen, W., \& Roe, R. A. (2008). Beyond the three-component model of organizational commitment. Journal of Applied Psychology, 93(1), 70-83. https://doi.org/10.1037/0021-9010.93.1.70

Document status and date:

Published: 01/01/2008

DOI:

10.1037/0021-9010.93.1.70

Document Version:

Publisher's PDF, also known as Version of record

\section{Please check the document version of this publication:}

- A submitted manuscript is the version of the article upon submission and before peer-review. There can be important differences between the submitted version and the official published version of record.

People interested in the research are advised to contact the author for the final version of the publication, or visit the DOI to the publisher's website.

- The final author version and the galley proof are versions of the publication after peer review.

- The final published version features the final layout of the paper including the volume, issue and page numbers.

Link to publication

\footnotetext{
General rights rights.

- You may freely distribute the URL identifying the publication in the public portal. please follow below link for the End User Agreement:

www.umlib.nl/taverne-license

Take down policy

If you believe that this document breaches copyright please contact us at:

repository@maastrichtuniversity.nl

providing details and we will investigate your claim.
}

Copyright and moral rights for the publications made accessible in the public portal are retained by the authors and/or other copyright owners and it is a condition of accessing publications that users recognise and abide by the legal requirements associated with these

- Users may download and print one copy of any publication from the public portal for the purpose of private study or research.

- You may not further distribute the material or use it for any profit-making activity or commercial gain

If the publication is distributed under the terms of Article $25 \mathrm{fa}$ of the Dutch Copyright Act, indicated by the "Taverne" license above, 


\title{
Beyond the Three-Component Model of Organizational Commitment
}

\author{
Omar N. Solinger, Woody van Olffen, and Robert A. Roe \\ Maastricht University
}

\begin{abstract}
This article offers a conceptual critique of the three-component model (TCM) of organizational commitment (Allen \& Meyer, 1990) and proposes a reconceptualization based on standard attitude theory. The authors use the attitude-behavior model by Eagly and Chaiken (1993) to demonstrate that the TCM combines fundamentally different attitudinal phenomena. They argue that general organizational commitment can best be understood as an attitude regarding the organization, while normative and continuance commitment are attitudes regarding specific forms of behavior (i.e., staying or leaving). The conceptual analysis shows that the TCM fails to qualify as general model of organizational commitment but instead represents a specific model for predicting turnover. The authors suggest that the use of the TCM be restricted to this purpose and that Eagly and Chaiken's model be adopted as a generic commitment model template from which a range of models for predicting specific organizational behaviors can be extracted. Finally, they discuss the definition and measurement of the organizational commitment attitude. Covering the affective, cognitive, and behavioral facets of this attitude helps to enhance construct validity and to differentiate the construct from other constructs.
\end{abstract}

Keywords: organizational commitment, attitudinal theory, theory of reasoned action, conceptual analysis

It has been over 15 years since Allen and Meyer (1990) proposed a three-component model of organizational commitment (TCM), on the basis of the idea that organizational commitment comes in three distinct forms: affective attachment to the organization, perceived costs of leaving it, and a felt obligation to stay. These three forms, labeled affective, continuance, and normative commitment, respectively, are referred to as components of organizational commitment. The affective component is defined as employees' emotional attachment to, identification with, and involvement in the organization. The continuance component is defined as the perception of costs associated with leaving the organization. Finally, the normative component refers to employees' feelings of obligation to remain with the organization. As such, the TCM ties together three separate streams of earlier commitment research (Becker, 1960; Buchanan, 1974; Kanter, 1968; Mathieu \& Zajac, 1990; Mowday, Porter, \& Steers, 1982; Salancik, 1977; Wiener, 1982; Wiener \& Vardi, 1980). Common to these three streams is the notion of a "psychological state that links an individual to an organization (i.e., makes turnover less likely)" (Allen \& Meyer, 1990, p. 14).

To date, the three-component conceptualization of organizational commitment can be regarded as the dominant model in organizational commitment research (e.g., Bentein, Vandenberg, Vandenberghe, \& Stinglhamber, 2005; Cohen, 2003; Greenberg \&

Omar N. Solinger, Woody van Olffen, and Robert A. Roe, Department of Organization \& Strategy, Maastricht University, Maastricht, the Netherlands.

Woody van Olffen is now at the Department of Strategic Management and Business Environment, RSM Erasmus University, Rotterdam, the Netherlands.

Correspondence concerning this article should be addressed to Omar N. Solinger, Department of Organization and Strategy, P.O. Box 616, Maastricht University, Maastricht, the Netherlands.
Baron, 2003). Nevertheless, an accumulation of studies have shown that the model is not fully consistent with empirical findings (Allen \& Meyer, 1996; Ko, Price, \& Mueller, 1997; McGee \& Ford, 1987; Meyer, Stanley, Herscovitch, \& Topolnytsksy, 2002). To overcome these problems, a revision of scales has been proposed (Meyer, Allen, \& Smith, 1993; Powell \& Meyer, 2004) However, some scholars have argued that the empirical inconsistencies derive not from faulty operationalizations but rather from deeper rooted problems regarding the underlying concepts (e.g., Ko et al., 1997; Vandenberg \& Self, 1993). This article identifies and discusses these problems through a systematic conceptual analysis of the TCM.

We start off with briefly reviewing the theoretical assumptions underlying the TCM and the main points of criticism that have emerged from empirical research over the last 15 years. Then we use the attitude-behavior model by Eagly and Chaiken (1993) to offer a conceptual critique of the TCM, which leads to the conclusion that the model is inconsistent and that affective, normative, and continuance commitment cannot be considered as components of the same attitudinal phenomenon. We extend our criticism to the rebuttals by Meyer and Herscovitch (2001) and their proposal to interpret TCM in motivational rather than attitudinal terms, and we determine that this reinterpretation fails to resolve the basic inconsistency. Our conclusion is that the TCM is, in fact, a model for predicting turnover. From this perspective, we reinterpret some typical findings from commitment studies. In the second part of the article, we propose to return to the conceptualization of organizational commitment as a singular construct - that is, an attitude with respect to the organization - and to use the Eagly and Chaiken model as a basis for generating specific models that can predict various organizational behaviors beyond turnover. We conclude with discussing the merits of a purely attitudinal definition of organizational commitment - covering affective, cognitive, and behavioral facets-in differentiating it from similar constructs 
and for enhancing the construct validity of measurement instruments.

\section{Critical Analysis of the TCM}

The TCM proposes that affective, continuance, and normative commitment - although different in nature-describe a link between the employee and the organization that decreases the likelihood of turnover. In the words of Allen and Meyer (1990), "Employees with strong affective commitment remain because they want to, those with strong continuance commitment because they need to, and those with strong normative commitment because they feel they ought to do so" (p. 3).

Three aspects are noteworthy when we consider the presumed common conceptual ground of the three components. First, all three components are supposed to reflect a psychological state (i.e., want, need, ought) of an employee vis-à-vis the organization, which made Allen and Meyer (1990) speak of attitudinal forms of commitment. Second, the three states are supposed to relate to the organization, reflecting the idea that organizational commitment is an attitude that has the organization as its object. Third, the three states can be present simultaneously-hence the conceptualization in terms of components (Allen \& Meyer, 1990) and the suggestion that the resulting total organizational commitment should be seen as the net sum of these three psychological states.

There is a more recent formulation of the TCM that retains the main ideas but proposes a motivational—rather than attitudinalinterpretation (Meyer \& Herscovitch, 2001). Since the dimensions and definitions of this revised model are exactly the same, it is equally sensitive to our critique. Yet we think it is useful to address the proposed reformulation as well. For the sake of clarity, we first scrutinize the original TCM and then extend our analysis to the motivational version.

\section{Inconsistencies in Empirical Research}

Empirical criticism of the TCM has mainly revolved around two construct validity topics - that is, the position of continuance commitment as a dimension of the overall commitment construct, and the relation between normative and affective commitment (e.g., Allen \& Meyer, 1996; Cohen, 2003; Meyer et al., 2002). First, continuance commitment generally correlates slightly negatively or not at all with affective commitment, important affective or attitudinal correlates, and important work-related outcome variables, such as organizational citizenship behaviors and job performance (e.g., Cohen, 2003; Dunham, Grube, \& Castaneda, 1994; Hackett, Bycio, \& Hausdorf, 1994; Ko et al., 1997; Meyer et al., 2002). In a recent meta-analysis, Meyer et al. (2002) found a corrected correlation coefficient of .05 between continuance and affective commitment (based on 92 different studies). Continuance commitment yielded correlations of .03 with job involvement (16 studies) and -.07 with overall job satisfaction (69 studies). Correlations with work-related outcome variables were -.01 for organizational citizenship behavior ( 22 studies) and -.07 for overall job performance (25 studies). This casts doubt on the convergent validity of continuance commitment. McGee and Ford (1987) specifically addressed the lack of convergent validity of the Continuance Commitment Scale and proposed two subdimensionsLack of Alternatives and High Sacrifices. In response to this latter criticism, Meyer et al. (2002; Powell \& Meyer, 2004) recently proposed to change the content of the Continuance Commitment Scale by retaining only High Sacrifices items, which refer to unrecoverable investments in the organization by the individual.

Second, normative commitment has consistently been found to correlate very strongly with affective commitment (e.g., a corrected correlation of .63, based on 54 studies; Meyer et al., 2002). Different studies (Ko et al., 1997; J. A. Lee \& Chulguen, 2005) have suggested that it is hard to separate normative commitment from affective commitment empirically. This apparent lack of discriminant validity led Ko et al. (1997) to regard the normative dimension as redundant, a position that is supported by findings showing that some antecedents of normative commitment correlate similarly with affective commitment. For example, selfpresentation concerns were found to correlate .49 and .50 with affective and normative commitment, respectively, while expectations of others correlated .42 and .62, respectively (Powell \& Meyer, 2004; see also Organ \& Ryan, 1995).

Empirical dimensionality problems of the TCM prompted Meyer and colleagues (e.g., K. Lee, Allen, Meyer, \& Rhee, 2001; Meyer et al., 1993; Powell \& Meyer, 2004) to revise and improve the instruments used for measuring continuance and normative commitment. However, it seems that the underlying problem with these components is conceptual rather than empirical in nature (cf. Bergman, 2006; Ko et al., 1997; Vandenberg \& Self, 1993). Unstable factor structures underlying the TCM over time have raised considerable concern about the ideas behind the model. Vandenberg and Self (1993), who detected these "gamma changes," maintained that these were "less of a case of true gamma change, and more a case of severe model misspecification" ( $p$. 566).

Ko et al. (1997) have therefore proposed a return to the view that organizational commitment is only an affective attachment, as proposed by Mowday et al. (1982), as long as the ambiguity surrounding the TCM remains unresolved. Their preference for the affective component is not surprising since-in contrast with the other components-it represents the most reliable and strongly validated dimension of organizational commitment (Cohen, 2003; Allen \& Meyer, 1996; Meyer et al., 2002), and it has the greatest content and face validity (cf. Brown, 1996; Dunham et al., 1994). Moreover, of all three dimensions, affective commitment was found to correlate the strongest. For example, in their metaanalysis, Meyer et al. (2002) reported corrected correlations of affective, normative, and continuance commitment with absence $(-.15, .05$, and .06$)$, performance $(.16, .06$, and -.07$)$ and organizational citizenship behaviors $(.32, .24$ and -.01$)$. These findings confirmed results reported in Stanley, Meyer, Topolnytsky, and Herscovitch (1999; Meyer \& Herscovitch, 2001). Affective commitment has also been found to correlate with the widest range of behavioral criterion variables (Meyer \& Herscovitch, 2001; Stanley et al., 1999). Examples of the latter are ample: Affective commitment yielded significant standardized beta weights with helping others (.15; Meyer, Allen, \& Smith, 1993), working extra hours (.12; Meyer et al., 1993.), voice (.20; Meyer et al., 1993), information sharing (.28; Randall, Fedor, \& Longenecker, 1990), quality concerns (.26; Randall et al., 1990), and supervisor evaluation of performance (.18; Meyer et al., 1993), while the two other components did not, although in the latter case continuance commitment tended to show a significant negative beta weight 
(-.10). Examples of the reverse (normative or continuance commitment correlating significantly with behavioral outcome variables, while affective commitment does not) are very rare (Allen \& Meyer, 1996). Reflecting on these results, Somers (1995) argued that the "emphasis on affective commitment evident in many prior studies was not entirely misplaced" (p. 55). For all these reasons, affective commitment has been preferred as the core concept of organizational commitment by many authors (e.g., Brickman, 1987; Brown, 1996; Buchanan, 1974; Mowday et al., 1982), and it has been used as the sole indicator of commitment to the organization in many recent studies (Armstrong-Stassen, 2006; Harrison, Newman, \& Roth, 2006; Kuvaas, 2006; Payne \& Webber, 2006; Sturges, Conway, Guest, \& Liefooghe, 2005; Van Dyne \& Pierce, 2004). To date, most of the criticism of the TCM has been empirical in nature. Although some authors have hinted at possible conceptual problems underlying these difficulties, these have not yet been systematically charted.

\section{Organizational Commitment as an Attitudinal Phenomenon}

There is widespread agreement in the literature that organizational commitment is an attitude (e.g., Allen \& Meyer, 1990; Angle \& Perry, 1981; Buchanan, 1974; Jaros, Jermier, Koehler, \& Singigh, 1993; Mowday et al., 1982; O'Reilly \& Chatman, 1986). Some scholars have referred to commitment as a psychological state (Allen \& Meyer, 1990), and others have referred simply to a bond or linking (Mathieu \& Zajac, 1990; Mowday et al., 1982) of the individual to the organization; an affective attachment (Buchanan, 1974); an orientation (Sheldon, 1971); a "readiness to act" (Leik, Owens, \& Tallman, 1999); or an "unconflicted state of internal readiness" (Brickman, Janoff-Bullman, \& Rabinowitz, 1987). All these descriptions display a structural similarity to what is commonly understood as an attitude: a person's internal state preceding and guiding action, comprising feelings, beliefs, and behavioral inclinations (Ajzen, 2001; Ajzen \& Fishbein, 1980; Eagly \& Chaiken, 1993).

Since organizational commitment is so widely seen as an attitude, we consider it appropriate to scrutinize the TCM using a dominant and well-validated paradigm of attitudes: the theory of reasoned action (Ajzen \& Fishbein, 1980; Fishbein \& Ajzen, 1975). More specifically, we refer to Eagly and Chaiken (1993), who have elaborated this theory in a model that clarifies how attitudes toward targets relate to attitudes toward behaviors. The model is depicted in Figure 1. The examples have been chosen to show how the model applies to the TCM-that is, they pertain to commitment to the organization (target) and to leaving the organization (behavior).

Central to the model is the attitude toward a specific behavior. This attitude directly leads to an intention (i.e., the conscious plan to carry out the behavior) and subsequently to the actual behavior. In the model, attitudes toward behaviors originate from the activation of habits, attitudes toward targets, and three classes of anticipated outcomes of behaviors: utilitarian, normative, and selfidentity. Habits need to be understood as sequences or repetitions of behaviors that have become relatively automatic (e.g., Triandis, 1977; Wood, Quinn, \& Kashy, 2002). As shown by the various arrows in Figure 1, habits such as going to work every day are likely to lead to a positive evaluation of staying with the organi- zation, since it is seen as a normal-hence, positive-thing to do (e.g., "I am going to work every day, so I might as well continue doing that"). It can also lead to a positive evaluation of the organization (i.e., the target) - "I am going to work every day, so I must like this organization"- or simply lead directly to the behavior without any deliberation or conscious thought. Attitudes toward targets consist of the evaluation of the persons or institutions (i.e., targets) toward which behaviors are directed. Next are the evaluations of various outcomes of behaviors. For example, the individual can perceive potential drawbacks associated with leaving the organization, such as losing pension plan guarantees (i.e., utilitarian outcomes), feelings of guilt or shame toward colleagues or the institution itself (i.e., normative outcomes), or incongruence with the self-concept, such as that of being a "good soldier" (i.e., self-identity outcomes). According to Eagly and Chaiken (1993), the antecedents of an attitude toward a behavior (i.e., habits, attitude toward a target, utilitarian outcomes, normative outcomes, and self-identity outcomes) all influence each other as well (see the connecting arrows in Figure 1). For instance, the habit of coming to work every day should also influence self-identity (e.g., "I come to work every day, so I must be a good and faithful soldier") or imagined utilitarian outcomes of leaving (e.g., "I am so used to working for this organization, that the cost of leaving is too high").

The TCM fits very well within the Eagly and Chaiken (E\&C) model. First, because affective commitment in the TCM is defined as "an employee's emotional attachment to, identification with, and involvement in the organization" (Allen \& Meyer, 1990, p. 14 ), it clearly represents an attitude toward a target in terms of the E\&C model. Note that affective commitment thus reflects an emotional attachment to the organization as a target, not to the behavioral act of leaving or remaining with the organization. Second, continuance commitment is defined as the perception of costs associated with leaving the organization (Meyer \& Allen, 1991, p. 67). This corresponds to "utilitarian outcomes," consisting of "rewards and punishments that are perceived to follow from engaging in the behavior" (Eagly \& Chaiken, 1993, p. 209). Continuance commitment simply reflects the consideration of instrumental outcomes of a course of action: stay or go. It is-in other words - an attitude toward behavior, not toward the organization or the target. Finally, normative commitment-employees' feelings of obligation to remain with the organization (Meyer \& Allen, 1991, p. 67) - fits both the normative outcomes and the self-identity outcomes in the E\&C model, depending on whether the felt obligations are derived from anticipated (dis)approval of significant others or from (in)consistency with conceptions of self. Normative outcomes pertain to "approval or disapproval that significant others are expected to express after performing the behavior as well as the self-administered rewards (pride) and punishments (guilt) that follow from internalized moral rules" (Eagly \& Chaiken, 1993, p. 210). Self-identity outcomes are "affirmations or repudiations of the self-concept that are anticipated to follow from engaging in the behavior" (Eagly \& Chaiken, 1993, p. 210). For example, a person who considers himself or herself as a good soldier (e.g., Organ, 1988) has a generalized sense of duty to serve the purposes of his or her organization. For this worker, leaving the organization will be associated with repudiating his or her selfconcept. A generalized sense of duty (derived from self-identity) is an internalized moral obligation (Eagly \& Chaiken, 1993; Meyer \& Allen, 1997; Shamir, 1991; Wiener, 1982) and, hence, part of 


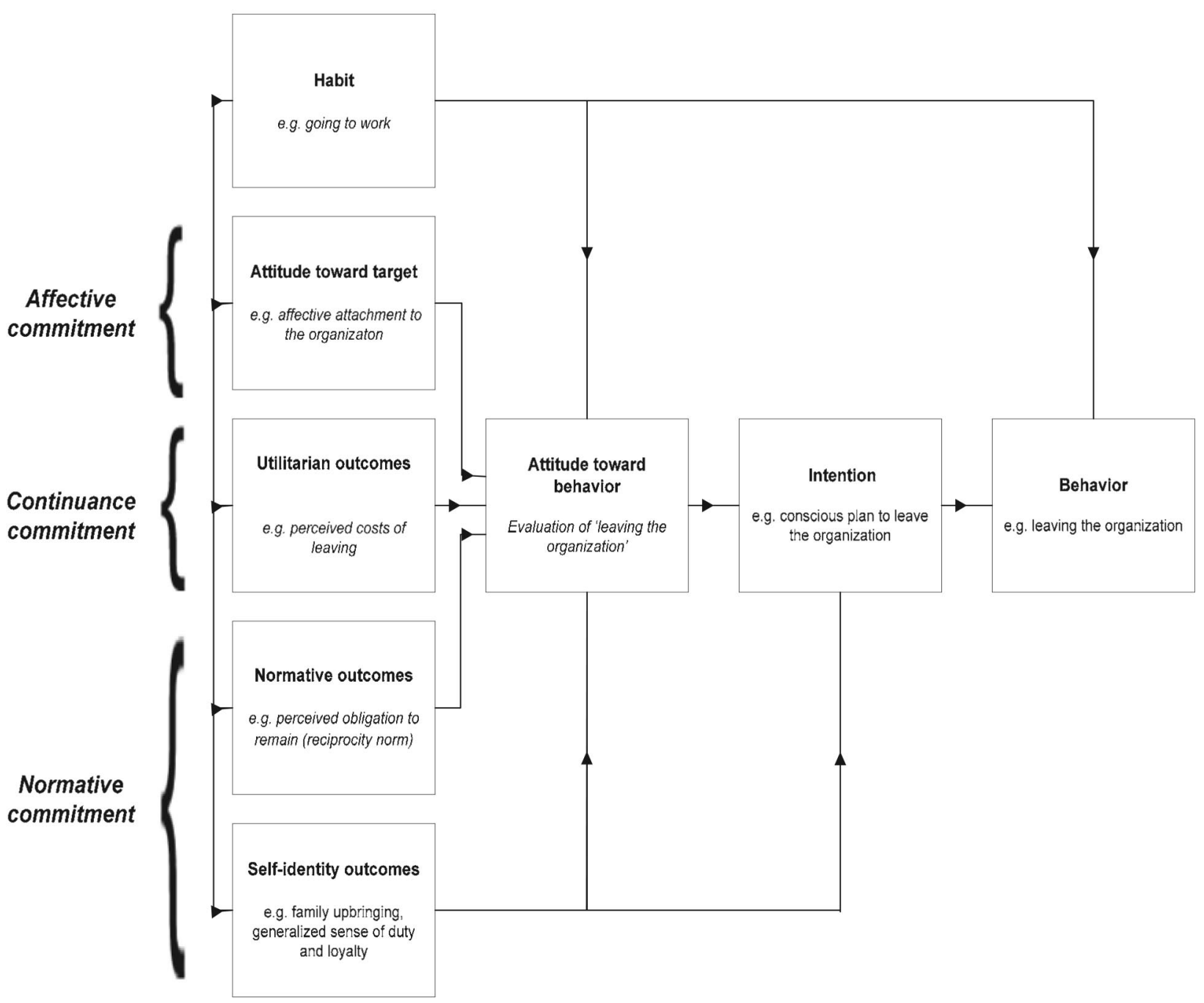

Figure 1. Eagly and Chaiken's (1993) composite attitude-behavior model linked to the three-component model of organizational commitment.

normative commitment. On the whole, it appears that normative commitment could be interpreted as the combination of considering normative outcomes and self-identity outcomes of behavior in terms of the $\mathrm{E} \& \mathrm{C}$ model. This distinction within normative organizational commitment between self and others is new and intriguing and warrants further investigation.

In sum, it appears that the TCM can be seen as a specific application of Eagly and Chaiken's (1993) model of the attitude-behavior relation in a workplace context. However, placed within this more general model, it also becomes clear that affective commitment equals an attitude toward a target, while continuance and normative commitment represent qualitatively different concepts: They refer to anticipated outcomes of a behavior, namely the act of leaving. From this, we conclude that organizational commitment as conceived in the TCM is not a unitary concept and that grouping target attitudes and behavior attitudes under one general label is confusing and logically incorrect.
The attitude-behavior model by Eagly and Chaiken (1993) can give alternative explanations for something that is seen as contradictory in a multidimensional conception of the TCMthat is, the finding that affective commitment-when compared to normative and continuance commitment-shows stronger associations with relevant behaviors and is associated with a wider range of behaviors, as we have discussed above (Allen \& Meyer, 1990; Meyer \& Allen, 1997; Meyer \& Herscovitch, 2001; Meyer et al., 2002). These contradictions may be ascribed to the conceptual inconsistency in the TCM of conflating an attitude toward a target with an attitude toward a behavior. For instance, suppose-using the TCM-we explain individuals' concerns for quality in the organization by their normative commitment. We then actually explain concern for quality by a felt obligation to stay with the organization. That is, Behavior A (i.e., maintaining concern for quality) is predicted by the normative pressure to perform Behavior B (i.e., staying). It is not surprising that low correlations are found (Randall et al., 
1990). Similarly, studies consistently have found insignificant relationships between continuance commitment and organizational citizenship behaviors (Meyer et al., 2002), because the former is defined and operationalized as a perceived cost to leave the organization. So, again, Behavior A (acting as a citizen) is explained by the disutility of Behavior B (leaving). Much higher associations are to be expected when actual quality concerns are predicted by normative attitudes toward (related) quality-enhancing behavior or when citizenship behavior is explained by the (related) utility of behaving as a citizen. Moreover, since an attitude toward a target (i.e., the organization) is obviously applicable to a wider range of behaviors than an attitude toward a specific behavior (i.e., staying), it does not come as a surprise that affective commitment is associated with a wider range of outcome variables as compared to normative and continuance commitment, as was noted above. We must conclude, therefore, that the TCM is inconsistent in focus. Affective organizational commitment is an attitude toward the organization, whereas continuance and normative organizational commitment are attitudes toward leaving the organization derived from imagined consequences. It should also be noted that-although the E\&C model is generic in nature-we intend to use the model exclusively in the context of organizational commitment and its relation to relevant organizational behaviors and confine our criticism to this domain.

\section{Rebuttals and Reformulations}

The critique that the TCM is conceptually inconsistent has been raised before (e.g., Brown, 1996). Unfortunately, however, this has not discouraged the use of the model or led to a fundamental revision. Instead, over the years, proponents of the TCM have given a number of rebuttals and proposed some reformulations in defense of the model. Below, we outline and discuss three major issues raised in this context.

The commitment-behavior relationship is easy to infer. Meyer and Herscovitch (2001) have defended the TCM by claiming that differences in focus within the model are merely a difference in emphasis and that the relevance of the different foci can be easily inferred.

Careful consideration of existing uses of the term commitment suggests that differences in focus are largely a function of emphasis. When commitment is considered to be directed at an entity, the behavioral consequences are often implied, if not stated explicitly. Similarly, when commitment is considered to be to a course of action, the entity to which that behavior is relevant can often be inferred even when not stated explicitly. (p. 309)

This argument is not totally convincing. Apart from the fact that the double use of the word often poses a barrier to logical refutation, various objections can be raised. First, behaviors are not necessarily implied in commitments, nor do behaviors necessarily allow the inference of targets. Committed employees can leave for various reasons (e.g., better career opportunities elsewhere, family circumstances), whereas noncommitted employees can stay for reasons of being locked in financially or because of lack of opportunities on the labor market (Lee \& Mitchell, 1994). It is even possible that individuals are committed after they have left the organization, as seems to happen after retirement (Cude \& Jablin, 1992).
Second, it is questionable whether a consistent relationship between organizational commitment and commitment to behaviors can exist at all. People who are highly committed to their organizations are unlikely to show the same behaviors over time. Instead, the behavior to express commitment changes as careers unfold (e.g., Katz, 1997). For instance, Buchanan (1974) has argued that early in the career, behaviors are important that secure one's position (e.g., trying to please a supervisor). During the 2 nd through the 4th year, the emphasis is rather on achievement, on making a mark (Hall \& Nougaim, 1968). This wish to make a difference may drive the committed employee to take on a lot of responsibility and to work overtime for the benefit of the organization. At the final stage, that of consolidation, committed employees engage in behaviors such as introducing recruits in the organization or mentoring and may even prepare for leaving the organization to enjoy a pension plan. Moreover, apart from the different expressions given to it, the level and meaning of organizational commitment itself are likely to change over time. They will vary in response to changes in the employment relationship through promotions, transfers, and new career stages (Bentein et al., 2005; Cohen \& Freund, 2005; Fuller et al., 2003). Such changes in commitment may be accompanied by a wide range of behaviors and produce relationships between commitment and behaviors that are far more complex than the simple pattern suggested by Meyer and Herscovitch (2001). To date, there is not sufficient empirical evidence to draw firm conclusions about the consistency over time between commitment to the organization as a target and commitment to specific behaviors. However, the available evidence seems to disconfirm the idea of a stable link. Several studies (e.g., Cohen, 1991; Mowday et al., 1982; Reichers, 1986) have shown that the relationship between commitment and specific behavioral outcomes depends on the career stage. This is congruent with findings on the links between job attitudes and work behaviors (Slocum \& Cron, 1985; Stumpf \& Rabinowitz, 1981; Super, 1957).

A third and final objection is that commitment to a target and commitment to a behavior differ in nature. Commitment to a target (i.e., the organization) is an attitude that predisposes the individual to a variety of behaviors under a wide range of conditions. Commitment to behaviors is - by definition - a much more restricted concept that only makes sense in settings and in moments for which these behaviors are relevant. Thus, for instance, neither continuance commitment nor normative commitment makes sense immediately after entry into a new organization or just before retirement. When it comes to situations in which employees are expected to perform their work tasks, to adjust to organizational change, or to help overcome difficulties by means of citizenship behaviors, commitment to the organization is relevant, while commitment to the behavior of leaving is not.

In conclusion, if we acknowledge that behaviors change over time in nature and in relevance to commitment, then inferring someone's commitment from specific behaviors inevitably leads to spurious results. In fact, this might very well explain why Vandenberg and Self (1993) encountered so-called gamma differences (i.e., changes in the underlying construct; see Terborg, Howard, \& Maxwell, 1980) when using the TCM in assessing newcomer's changing commitments to their organization over time. In line with our arguments above, the use of 
behaviors as indicators of evaluations of targets (especially over longer time spans) might have led to the observed gamma differences. Knowing that the TCM incorporates evaluations of behaviors as well as targets, we can conclude that the model includes different concepts that cannot be represented by a single construct in a theoretically meaningful way. ${ }^{1}$ As the behavioral expression of attitudes toward targets changes over time, an attitude toward a target and an attitude toward specific behavior cannot meaningfully reflect a single underlying construct.

Attitudes and behaviors influence each other reciprocally over time. Another justification that Meyer and Herscovitch (2001) have provided for combining attitudes toward a target and attitudes toward a behavior in a single construct is that " the attitude versus behavior distinction relates more to the processes involved in the development of commitment than to the focus of commitment" ( $\mathrm{p}$. 309). Attitudinal (affective) commitment and behavioral approaches to commitment might become integrated in an ongoing reciprocal influence process. To illustrate their point, Meyer and Allen (1991) provided the following example:

Employees who perform at a high level of proficiency may become (behaviorally) committed to that level of performance and, consequently, develop a more positive attitude (affective commitment) toward the organization. Such an attitude, once developed, may insure the continuation of a high level of performance in the future. (p. 78)

There are a number of problems with this statement. First, we think this argument poses a logical problem. By stating that affective commitment and behavioral approaches to commitment are bound by an "ongoing reciprocal influence process" or that one works as an "antecedent" of the other, (Meyer \& Allen, 1991, p. 78 ), one implicitly assumes that two or more constructs are involved, not just one. Causal modeling and subsequent grouping of components into a higher order (multidimensional) construct is possible if - and only if - the components are conceptualized as separate constructs (cf. Edwards, 2001). Thus, if the TCM components indeed influence each other reciprocally over time, they cannot represent the same commitment construct.

Second, at a logical level, the argument is not refutable, since it asserts that something that may (or may not) happen can be associated with something else that may (or many not) happen. Third, at a psychological level, Meyer and Allen's argument hints at a type of reciprocal learning of which no empirical evidence exists yet (Bergman, 2006; Meyer, Allen, \& Gellatly, 1990). Although performance indeed has been found to be an antecedent to affective commitment, the correlations are still low (corrected correlation of .15 in 16 studies; Harrison et al., 2006). If the successful performance is attributed to unique conditions created by the organizations, significant correlation may indeed be found. However, if the performance is attributed to conditions inherent in the job or to unique qualities of the person himself or herself, it is not likely that greater organizational commitment will arise. One would rather expect greater job involvement or greater self-efficacy.

Fourth, even if a link between performance and organizational commitment did exist, it would be of limited relevance to the TCM, since the behavior in this model is not performance but leaving. Hence, time-lagged relations between affective and continuance commitment were found to be not significant and close to zero (Meyer et al., 1990). An important difference is that performance happens on a daily basis, while leaving happens relatively rarely in a person's career. It is highly questionable whether learning effects associated with daily performance would generalize to forming an attitude toward the (rarely occurring) act of discontinuing employment.

From binding to an object to binding to a course of action. In the same 2001 article, Meyer and Herscovitch proposed to rephrase the general idea behind the TCM by characterizing overall commitment as a commitment profile, signifying the pattern of relations among three mind-sets of commitment to the organization, designated as desire, cost, and obligation. The authors referred to overall commitment as "a force that binds an individual to a course of action, of relevance to one or more targets" (Meyer \& Herscovitch, 2001, p. 301). However, the three components were the same as before, and no formal definitions were given to replace the older ones. Instead of considering the attitude toward the organization as the common ground for the three components, Meyer and Herscovitch referred to "a course of action" as their common ground, mentioning that the course of action (e.g., staying) is relevant to the organization. Furthermore, they described these three forms as manifestations of a binding force rather than as distinct attitudinal forms. This alludes to a motivational interpretation of the commitment phenomenon, as elaborated by Meyer, Becker, and Vandenberghe (2004) in a more recent publication. Whether the motivational TCM must be seen as a revision of the older, attitudinal TCM is not fully clear. Since the attitudinal model has not been revoked, we are inclined to conclude that Meyer et al. (2004; Meyer \& Herscovitch, 2001) have merely offered an alternative interpretation of the same theoretical model and therefore maintain our criticism. Thus, affective commitment is still defined as focused on an entity (or target), and continuance and normative commitment are explicitly tied to acts toward remaining employed (a behavior).

Still, scrutiny of the motivational TCM offers ground for additional criticism. First of all, it seems to us that the proposed definition of overall commitment as "a force that binds an individual to a course of action of relevance to one or more targets" (Meyer \& Herscovitch, 2001, p. 301) suffers from severe underspecification, as it is in no way linked to the commitment phenomenon. The notion of force might refer to almost any motivating factor (e.g., goals, values, interests, needs) known in the field of organizational behavior (Latham \& Pinder, 2005; Pinder, 1998), and a "course of action" might refer to almost any behavior (e.g., selling products, presenteeism, creative action, sexual harassment,

\footnotetext{
${ }^{1}$ It might be argued that organizational commitment in the TCM could be seen as a formative rather than a reflective construct (Bergman, 2006; Bollen \& Lennox, 1991; Edwards \& Bagozzi, 2000) if translated in terms of a structural equations measurement model. To our knowledge, Meyer et al. (e.g., Meyer \& Allen, 1991; Meyer \& Herscovitch, 2001) have never proposed such a measurement model. While it might defend the TCM against criticism of low intercorrelations between the three components, a formative conceptualization would introduce more problems than it solved, such as the conceptual indeterminacy of the commitment construct, measurement inequivalence across studies (because of to dropping, altering, or adding indicators used to measure it), questionable construct validity when dependent variables other than turnover are used (cf. Bollen \& Lennox, 1991), and poor prediction of organizational behaviors other than turnover (which are not specified as indicators in the formative construct). However, most important, specifying the TCM as formative does not provide a solution to the conceptual inconsistency that underlies the TCM itself.
} 
joking, verbal abuse). As this reformulation is so broad as to lose any power of making specific predictions, it is unclear what theoretical or practical improvement it would bring.

However, Meyer and Herscovitch's (2001) point is well taken that - at least in the general definition-broadening the scope of behaviors does make the commitment model more suited to explaining behavioral outcomes other than turnover. Similar to the E\&C model, this rephrased model taps into different mental states (i.e., mind-sets of desire, cost, and obligation, representing the three commitment components) that can accompany the evaluation of a particular behavior. There is, however, a crucial distinction between the two models. When measuring organizational commitment using Meyer and Herscovitch's (2001) model, the researcher is forced to focus on one particular course of action (i.e., staying), leaving the potential relationships of the three mind-sets with other relevant behaviors aside. In contrast, when the researcher uses the E\&C model—which implies conceptually confining organizational commitment to an attitude toward a target-a wide variety of behaviors relevant to the commitment can be modeled, in combination with the various mental states (i.e., habits and imagined outcomes of behavior) that form the evaluation of the particular behavior. Thus, unlike the reformulated TCM, the E\&C model is more specific by explicitly disentangling attitudes toward targets and attitudes toward behaviors. Later in the article, we elaborate on the use of the E\&C model in commitment research.

The motivational TCM also fails to resolve the fundamental inconsistency we have pointed out above. Within a motivational perspective, the emotional attachment to the organization (affective commitment) brings about a general readiness to act (cf. Brickman, 1987; Eagly \& Chaiken, 1993)—-that is, a general tendency to perform a range of behaviors in favor of the organization. It applies to virtually any category of behaviorwhether broad or specific, immediate or long term, discrete or continuous (Shamir, 1991). Which behavior is viewed as appropriate to serve the organization depends on the specific situation and moment in the career (cf. Fazio \& Towles-Schwen, 1999). In contrast, the motivation to engage in a particular kind of behaviorthat is, to leave or stay-is of a different kind. Unlike the general readiness to act (Brown, 1996), it has a narrow focus and arises out of a number of personal and situational factors that are specifically tied to the behavior. The motivation to remain employed by a given employer, whether arising from an affective attachment, a felt obligation, a perceived cost of leaving, or any combination of these, does not generalize to the motivation toward other behaviors, while the motivational state described as a general readiness to act in favor of the organization does. This difference is in agreement with the results of motivational research, which have shown that the level of behavioral specificity leads to different motivational states (Gollwitzer \& Brandstätter, 1997; Gollwitzer, Heckhausen, \& Steller, 1990; Perugini $\&$ Bagozzi, 2004). In addition, as we have elaborated on before, there is a difference with regard to the time variable. At different moments in time, different behaviors may be most appropriate to express a commitment, while the more general action readiness remains relatively stable. This difference supports our earlier conclusion: If the motivation to perform a specific behavior changes over time in a way that is different from the action readiness inherent to an affective attachment, pulling these motivations together in a single construct obscures a relevant distinction.

\section{Conclusion}

Although we are not the first to criticize the TCM, our conceptual analysis has demonstrated that the TCM suffers from a basic shortcoming that cannot be repaired by modifying measurement or by reinterpreting the common ground in motivational terms. We therefore propose to respectfully abandon the TCM and return to the definition of organizational commitment as affective attachment to an organization (Brickman, 1987; Brown, 1996; Ko et al., 1997; Mowday, Steers, \& Porter, 1979). As the attitude-behavior model of Eagly and Chaiken (1993) implies, continuance and normative commitment should be seen not as commitments but rather as antecedents of attitudes toward a specific behavior, more precisely as different classes of imagined consequences of (dis)continuing employment. This classification still acknowledges the apparent importance ${ }^{2}$ of normative and continuance considerations for staying on the job, which is paramount in a vast number of studies on the matter (e.g., Meyer et al., 2002). However, when it comes to the prediction of other work-related outcomes, such as concern for quality or information sharing (Randall et al., 1990), it may be useful to include anticipations of the outcomes of those behaviors, which would, in turn, help create a different set of behavior-specific attitudes. Unmistakably, the TCM has served to enrich our knowledge on different motivational grounds of staying with and leaving an organization. However, for a better understanding of organizational commitment and its broader implications for organizations, we now need to move toward an unambiguous and parsimonious conceptualization.

\section{A Road Ahead for Organizational Commitment Research}

We see two steps to move ahead in organizational commitment research. First is the proper placement of the organizational commitment in a wider conceptual framework, which will allow researchers to model the relationship between organizational commitment and various organizational behaviors. Here, we propose to use the reasoned action model by Eagly and Chaiken (1993). The second step is a regrounding and measurement of organizational commitment itself as a truly attitudinal construct. Below we develop and illustrate both steps.

\section{Generating Models of Organizational Commitment- Organizational Behaviors}

The value of the E\&C model is not limited to showing the shortcomings of the TCM. In our view, it offers an alternative to the TCM that can explain the links between organizational commitment and several types of organizational behavior other than leaving and staying. While the E\&C model is a generic model that applies to any context in which it is appropriate to study the links between people's attitudes and behaviors, our proposal is to apply it to organizational contexts and use it for explaining behaviors shown by employees. In this case, the attitude toward the target (see Figure 1) can be equated to organizational commitment, and the behavior can be any type of organizationally relevant activity. The habits and imagined outcomes of behavior from the E\&C model

\footnotetext{
${ }^{2}$ In a meta-analysis, Meyer et al. (2002) reported corrected correlations of -.30 and -.20 with withdrawal cognition for normative and continuance commitment, respectively (over 33 studies).
} 
are specific to the organizational behaviors to be explained. There is ample empirical evidence showing that organizational commitment is related to a wide range of organizational behaviors, most prominently organizational citizenship behaviors (a corrected correlation of .26 inside and .46 outside the United States based on 22 studies reported in Meyer et al., 2002); work performance (.16 in 25 studies; Meyer et al., 2002); and various types of withdrawal behaviors, such as absenteeism ( -.15 in 10 studies; Meyer et al., 2002), intention to leave ( -.51 in 24 studies; Meyer et al., 2002), and actual turnover ( -.17 in 8 studies; Meyer et al., 2002). Previous meta-analyses on organizational commitment (Allen \& Meyer, 1996; Mathieu \& Zajac, 1990) showed similar results. This means that there is a rich empirical basis for developing commitment-behavior models.

Our expectation is that further research will considerably extend the range of behaviors to be explained from organizational commitment. Future research may profit from a typology of organizational behaviors that has emerged from research by Hirschman (1970); Farrell (1983); Rusbult and Zembroth (1983); and Hagedoorn, Van Yperen, Van de Vliert, and Buunk (1999). This twodimensional typology groups behaviors along a constructivedestructive axis and an active-passive axis. Although the original research focused on employees' responses to adverse organizational circumstances, the typology seems suitable for classifying any type of organizational behavior. Examples of constructive behaviors are championing (e.g., fundraising, personal recruitment, enhancing sales, boasting), ambassadorship (e.g., mentoring, role modeling, figure heading), customer orientedness (Morgan \& Hunt, 1994), showing quality concern (Randall et al., 1990), personal deprivation (e.g., sacrificing private time, sleep, or alternative employment opportunities), subservience (Adler \& Adler, 1988), organizational face saving (i.e., protecting the organization's image; Dutton, Dukerich, \& Harquail, 1994), "intrapreneurship," constructive voice (Mowday et al., 1982), prosocial behavior (O'Reilly \& Chatman, 1986), and proactivity during socialization (Wanberg \& Kammeyer-Mueller, 2000). While these behaviors all qualify as active, there are also behaviors of a passive nature, such as being patient (Farrell, 1983; Hagedoorn et al., 1999), abiding with organizational norms (Kunda, 1992), and engaging in praiseful gossip (Gluckman, 1963; Noon \& Delbridge, 1993).

On the destructive side are withdrawal behaviors such as absenteeism and tardiness (Meyer et al., 2002) and a number of deviant behaviors, some of which can be quite harmful to the organization and to its employees (Robinson \& Bennett, 1995; Skarlicki \& Folger, 1997). Among these are corporate illegal behaviors (i.e., property or production deviance; e.g., theft), workplace aggression (e.g., bullying, verbal abuse, sexual harassment, violence), engaging in retaliatory behaviors (e.g., active resistance, sabotage), leaking to the press (e.g., whistle blowing), working to rule, withholding vital information (Randall et al., 1990), and displaying political deviance (e.g., extreme interdepartmental antagonizing, blaming, favoritism; Robinson \& Bennett, 1995). While most of these behaviors can be considered as active, some of them (e.g., working to rule and withholding vital information) can be seen as passive. Other examples of passive behavior are neglect (Farrell, 1983; Hagedoorn et al., 1999), cynical talk (Ford, Ford, \& McNamara, 2002), and shirking (Robinson \& Bennett, 1995).

Our position is that for each of these types of organizational behavior, a specific commitment-behavior model can be developed on the basis of the E\&C model. To illustrate the approach, we have chosen a behavior in the active-negative quadrant, namely employee theft. This particular behavior seems to be the fastest growing type of workplace deviance in the United States. Depending on the definition of nontrivial employee theft, incidence rates among employees have been estimated to lie between $50 \%$ to $75 \%$; estimated financial losses range from of $\$ 40$ billion to $\$ 120$ billion annually (Case, 2000; Coffin, 2003; Wimbush \& Dalton, 1997). In the organizational behavior literature, employee theft is predominantly seen as a retaliatory reaction to a perceived inequity or injustice (e.g., Greenberg, 1990; Skarlicki \& Folger, 1997). Figure 2 shows how the E\&C model could be used to generate a commitment-behavior model that predicts the occurrence of theft.

Employees who feel disappointed by their employers or experience inequity in their relationship are likely to lower their commitment to the organization (Brown, 1996). They psychologically distance themselves from their employer to avoid harmful consequences to the self. As a consequence, they feel less attached (affect), they think less favorably about the organization (cognition), and they decrease their readiness to serve the organization's interests (action). This decline in organizational commitment may lift constraints on behaviors that might harm the organization and creates room for retaliatory action, including stealing.

Whether employees actually engage in stealing is affected by habit as well. Employees with a transgressive history (e.g., since childhood or during their stay with the organization) are likely to evaluate stealing as not such a big a deal and engage in stealing on a regular basis. Among habitual thieves, one may find directly formed attitudes toward stealing that are consistent with their habit (Salancik, 1977; Wood et al., 2002). At the opposite end are employees who have never stolen anything from their employer and who have neither the habit nor the attitude of stealing.

Utilitarian outcomes (i.e., potential rewards and punishments associated with the behavior) are generally assessed with an expectancy-value paradigm (e.g., Eagly \& Chaiken, 1993; Scholl, 1981). In the case of stealing, individuals weigh its potential benefits against its potential costs. More specifically, they weigh the likelihood that the attempt to steal will be successful and the value of owning the object without payment against the likelihood of getting caught and the value of its negative potential consequences. Normative outcomes of stealing can be experienced as a balance of the value of approval and the value of disapproval anticipated from significant others (Ajzen \& Fishbein, 1980). The employee might know many colleagues who consider stealing as normal and anticipate their consent, with the idea that he or she is doing the appropriate thing to get even with the employer. However, the employee might also anticipate feelings of guilt or shame toward the organization as a whole or toward significant others who clearly oppose the act of stealing. Again, the expectancy-value paradigm could be applied (Ajzen \& Fishbein, 1980; Eagly \& Chaiken, 1993; Fishbein \& Ajzen, 1975), since the (dis)approval of others may vary in likelihood and importance. Finally, self-identity outcomes enter into the equation. Individuals who have an idealist self-concept will be more inclined to hold negative attitudes toward the act of stealing than people with a realist self-concept (Henle, Giacalone, \& Jurkiewicz, 2005). All these influences might combine to form an attitude toward stealing. This attitude is expected to lead up to a conscious plan 


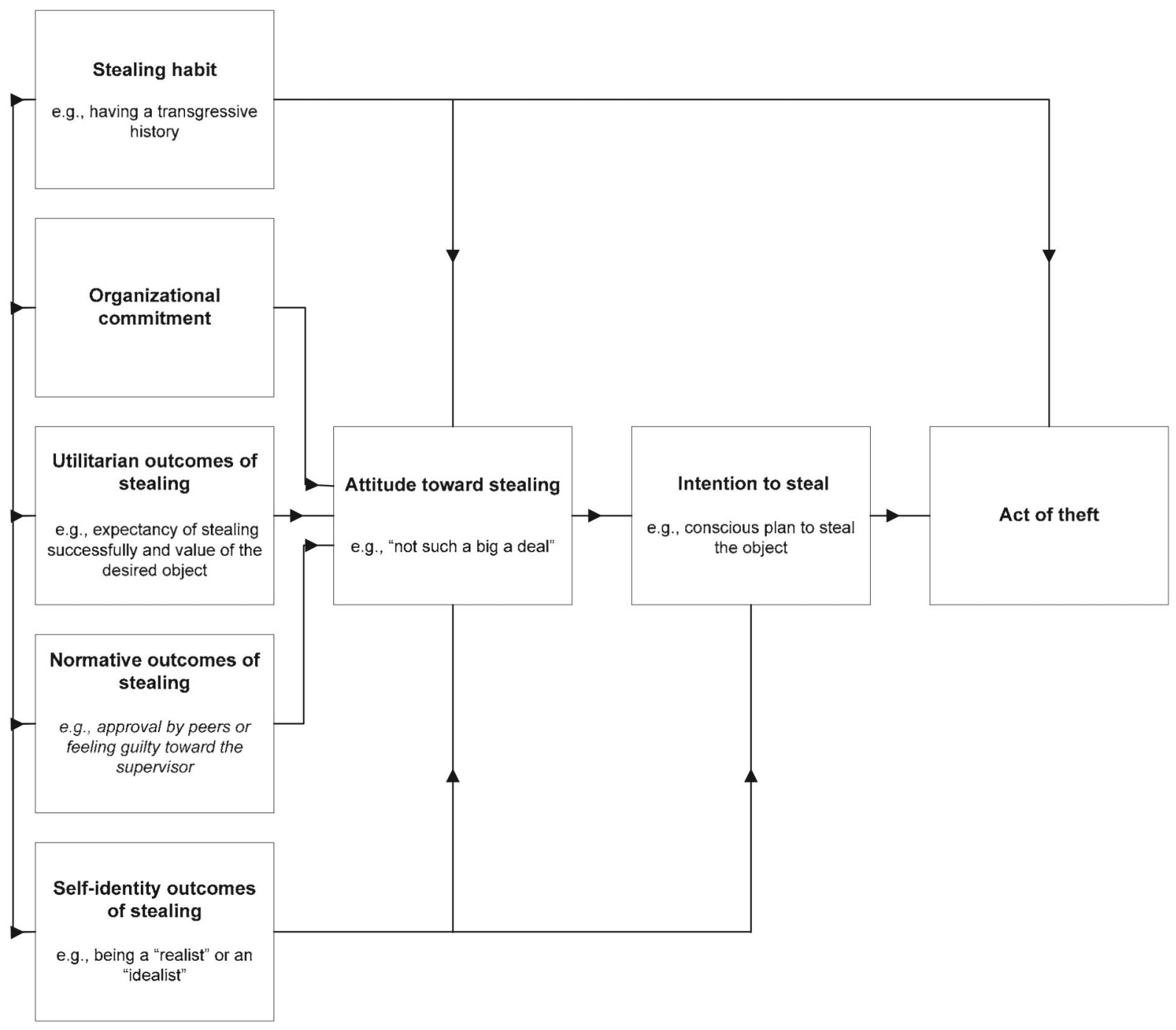

Figure 2. An application of Eagly and Chaiken's (1993) composite attitude-behavior model to corporate theft.

to steal something at a given time (i.e., the intention to steal), which is expected to result in the actual act of theft.

According to the resulting model, organizational commitment should be a major factor explaining employee theft. A lack of commitment might favor the development of a pro-stealing attitude. A pro-stealing attitude and a habit of stealing, in combination with a lack of commitment, will lead to a high probability of actual theft. High organizational commitment, conversely, will serve as a counterweight to bad habits and opportunism and be associated with a low probability of theft.

\section{Propositions Regarding E\&C-Type Models}

Generating commitment-behavior models on the basis of the E\&C model has a number of specific implications. First, organizational commitment should invariably be part of any such model. This means that commitment is given a central position in explanations of employees' behaviors toward their organization, regardless of whether the behavior is in the constructive or destructive category or in the active or passive category. Even though other factors affect the occurrence of particular behaviors, commitment is hypothesized to play a role in their emergence. This is in accordance with the outcomes of many research studies that were reviewed before (e.g., Allen \& Meyer, 1996; Mathieu \& Zajac, 1990; Meyer et al., 2002). Second, adding habits and anticipated outcomes of actions will improve the explanation of the behavior. Although the relative contribution of various factors may vary, depending on the type of behavior involved as well as the organizational context and/or employee population, together they will improve the explanation of the behavior over that given by organizational commitment alone. Third, the E\&C model shows (see Figure 1) that while the effect of organizational commitment on behavior is indirect (i.e., mediated), relevant behavioral routines (e.g., certain habits) may impact a particular behavior directly, even if the individual does not form an attitude toward that behavior or form an intention toward performing it (Eagly \& Chaiken, 
1993; Wood et al., 2002). This means that, in the presence of strong habits, the explanatory value of organizational commitment for specific behaviors may be reduced. In general, habits contribute to the explanation of particular behaviors both directly and indirectly - that is, mediated by an attitude toward the behavior and a corresponding intention.

Fourth, the most important contribution of E\&C-type models is the distinction between attitudes toward targets and attitudes toward behaviors. Eagly and Chaiken (1993) argued that the two are, in fact, separate constructs that are linked in a causal chain. This concurs with the assumption underlying the theory of reasoned action (Ajzen \& Fishbein, 1980; Fishbein \& Ajzen, 1975) that a thought of some sort must be formed to activate behavior: At a minimum, an intention must be formed to direct behavior. Empirically, this means that the relationship between attitudes toward targets and actual behaviors should be fully mediated by the attitudes toward the behavior and intentions. From these considerations, we derive the following propositions:

Proposition 1: Organizational commitment will significantly predict behavior in any category of the constructivedestructive and active-passive typology of organizational behaviors.

Proposition 2: If a particular behavior is predicted from organizational commitment, the degree of model fit will significantly improve when habits and anticipated outcomes of the behavior (i.e., utilitarian, normative, and self-identity) are taken into account.

Proposition 3: Habits will contribute to the prediction of a particular behavior both directly and indirectly-that is, through an attitude and an intention toward the behavior; the habit-behavior relationship will therefore be partially mediated.

Proposition 4: After habits and anticipated outcomes of behaviors are controlled, the relationship between organizational commitment and specific behavior will be fully mediated by the attitude toward the behavior and the intention to perform the behavior.

These propositions can best be tested by means of structural equations modeling. This type of analysis will allow us to assess the strength of commitment-behavior links, as mentioned in Proposition 1; the improvement of model fit when variables are added, as mentioned in Proposition 2; and the presence of specific mediation effects, as mentioned in Propositions 3 and 4. In general, it is to be expected that a gradual build-up of phenomena (e.g., adding habits, different classes of anticipated outcomes of behavior, and mediators consecutively) will result in increasing fit of the model, while a gradual reduction will result in decreasing fit.

\section{Limitations of E\&C-Type Models}

In spite of their advantages, commitment-attitude models based on the E\&C model also have their limitations. First of all, their applicability is restricted to behaviors that are performed consciously - that is, with a certain amount of cognitive deliberation (Eagly \& Chaiken, 1993; Fazio \& Towles-Schwen, 1999). For instance, it is not suitable to explain spontaneous, emotional, and/or reflexive behavior. Second, some factors that may moderate or complement the role of organizational commitment may be added. For example, perceived behavioral control can be derived from the theory of planned behavior (Ajzen, 1991) and added if needed. Third, the E\&C model does not necessarily give the best prediction of specific behaviors. For instance, better predictions of turnover could be achieved with the job embeddedness model developed by Mitchell, Holton, Lee, Sablynski, and Erez (2001), which has been shown to produce high effect sizes. However, the major advantage of generating models in the way advocated here, in contrast to developing specific models for predicting each and every type of organizational behavior, is that it results in a structurally homologous and therefore parsimonious set of models that can account for diverse effects of organizational commitment on employee behaviors. An even greater advantage of using the E\&C model is that it enhances the compatibility of organizational behavior research with more general theory on human behavior.

\section{Toward a Strictly Attitudinal Definition of Organizational Commitment}

Above, we have concluded that organizational commitment should be conceived as an attitude toward a target (i.e., the organization), and we have argued that this attitude offers a fruitful basis for predicting a variety of organizational behaviors. Although organizational commitment conceived in this way bears resemblance to the affective commitment construct from the TCM, we emphasize the importance of using a definition that does not restrict itself to the affective aspect but includes cognitive and behavioral aspects as well. Below, we argue that this helps to differentiate the organizational commitment from other constructs in the organizational behavior domain and will lead to greater construct validity of measurement instruments.

Standard attitudinal theory regards attitudes to be reflected in affect, cognition, and an action tendency (e.g., Ajzen, 2001; Ajzen \& Fishbein, 1980; Eagly \& Chaiken, 1993; Hollander, 1971). Any definition of commitment that honors its attitudinal character should therefore reflect this classic triplet. However, if we look at current definitions and conceptualizations of organizational commitment in the literature, we find a range of definitions that capture the affective and cognitive aspects of attitudes but do not include the action tendency. Apart from a failure to really capture the concept in its entirety, this also leads to severe problems of discriminant validity with competing concepts. For example, Van Knippenberg and Sleebos (2006) conceptualized commitment as an exchange-based attachment - which covers cognition and affect, not action, and is difficult to distinguish from the psychological contract (Rousseau, 1995). Likewise, when commitment is seen as predominantly value based (e.g., Meyer, Becker, \& Van Dick, 2006), it comes very close to constructs such as value congruence (O'Reilly, Chatman, \& Caldwell, 1991). These loose ways of defining commitment raise questions about the added value of the commitment construct and the need for using it at all. Our view is that a strictly attitudinal definition of organizational commitment not only differentiates the construct from these alternatives but also produces an added value when it comes to 
predicting actual behaviors. Note that this view corresponds with the early idea, expressed by Mowday et al. (1982), that organizational commitment goes beyond feelings and beliefs that could be experienced passively and incorporates a willingness to give something of oneself to contribute to the organization's success. ${ }^{3}$

It is important to emphasize that the tendency to perform actions in the interest of the organization (Eagly \& Chaiken, 1993) should be interpreted as a general tendency (i.e., with no reference to a specific behavior) or a general readiness to act (Brickman, 1987; Leik et al., 1999). Many classic qualitative studies (e.g., Adler \& Adler, 1988; Brickman, 1987; Brown, 1996; Wyatt, 1999) on the nature of commitment have displayed considerable consensus on what exactly constitutes this action readiness. They have argued that commitment is present when a person persists in a behavior even under circumstances that would otherwise have caused him or her to change that behavior. Put even more strongly, commitment implies an urge to perform behaviors that-by definitionexceed instrumental motivations of the individual (Buchanan, 1974; Scholl, 1981). Taken to the extreme, it can inspire individuals to go to great lengths and even sacrifice their own personal well-being for a greater good that they identify with —as in combat units, religious communities, or athletic teams (Adler \& Adler, 1988; Salancik, 1977; Shamir, 1991). A commitment starts when some form of vow is made. More precisely, it is the state at which one arrives after having made a pledge (Adler \& Adler, 1988; Brickman, 1987; Brown, 1996; Salancik, 1977). The stronger the pledge is (i.e., the more public, irrevocable, volitional, and explicit), the stronger will be the commitment attitude (Salancik, 1977). Thus, commitment does not come cheap: It is a binding vow, a generalized behavioral pledge to act in the interest of the organization. We therefore propose the following strictly attitudinal definition of organizational commitment:

Organizational commitment is an attitude of an employee vis-à-vis the organization, reflected in a combination of affect (emotional attachment, identification), cognition (identification and internalization of its goals, norms, and values), and action readiness (a generalized behavioral pledge to serve and enhance the organization's interests).

\section{The Measurement of Organizational Commitment}

Adopting a strictly attitudinal definition has implications for the measurement of organizational commitment. Allen and Meyer's (1990) questionnaire focuses predominantly on emotional attachment to (affect) and identification with the organization (affect and cognition). Its items respectively tap into the notions of the feeling of being happy to spend the rest of one's career with the organization, enjoyment of discussing the organization with people outside it, the degree to which the organization's problems are perceived as one's own, the ease of becoming attached to another organization, a feeling of being part of the family, emotional attachment, personal meaning, and belongingness (Allen \& Meyer, 1990). The notion of action is conspicuously absent. While this can be explained by the fact that the authors intended to measure affective commitment, it is a limitation that should be overcome if one wants to measure organizational commitment as an attitude. Other instruments (e.g., the Identification/Internalization Typology $^{4}$ by O'Reilly \& Chatman, 1986) show similar limitations. The only exception is the Organizational Commitment Questionnaire by Mowday et al. (1982). However, this instrument explicitly mentions a strong desire to remain employed (which is a specific behavior rather than a generalized behavioral pledge) and thus received the critique of producing inflated relationships with turnover (Bozeman \& Perrewe, 2001; O'Reilly \& Chatman, 1986; Reichers, 1985). In line with our attitudinal definition, we therefore suggest that existing instruments be expanded or refined to include all three attitude aspects. Such an expansion is necessary to improve the construct validity of these instruments in comparison to instruments measuring other constructs.

Proposition 5: The discriminant validity of organizational commitment vis-à-vis related constructs will improve when they are operationalized as a combination of affect (i.e., belongingness, identification), cognition (i.e., identification and internalization), and action readiness (i.e., a generalized behavioral pledge).

This proposition can be investigated empirically by means of standard methods for assessing construct validity, including factor analysis, structural equations modeling, and multitraitmultimethod analysis (Netemeyer, Bearden, \& Sharma, 2003; Netemeyer, Johnston, \& Burton, 1990; Nunnally \& Bernstein, 1994; Spreitzer, 1995).

\section{Conclusion}

In this article, we have shown that the TCM does not qualify as a general model of organizational commitment, as it suffers from a conceptual inconsistency and, hence, a lack of unequivocal empirical support. When looked on from the attitude-behavior model of Eagly and Chaiken (1993), it appears to combine an attitude toward a target (the organization) with attitudes toward a behavior (leaving or staying). While the TCM might be retained to predict employee turnover, its use as a general model of organizational commitment should be discouraged. In line with the predominant practice in research on organizational behavior, we propose to return to the original understanding of organizational commitment as an attitude toward the organization and to measure it accordingly. Future research may improve the discriminant validity of existing measures by giving due attention to the cognitive, emotional, and behavioral components of the commitment attitude. We have proposed the E\&C model as a viable alternative to the TCM and as a generic framework from which a variety of specific commitment-behavior models can be derived, all sharing organizational commitment as a common core. Unlike the TCM, in the E\&C model the predicted behaviors are not limited to staying with the organization or leaving it but represent a broad spectrum of organizational behaviors, such as corporate illegal behaviors,

\footnotetext{
${ }^{3}$ The action component also distinguishes the commitment construct from job satisfaction, which implies a more passive-or maybe even complacent—psychological state.

${ }^{4}$ O'Reilly and Chatman's (1986) commitment typology consists of compliance, identification, and internalization. In keeping with the authors' definition (i.e., "instrumental involvement for specific, external rewards," p. 493), the compliance component can be characterized as an evaluation of the utilitarian outcomes of behavior, not as a component of an attitude toward a target.
} 
shirking, organizational championing, satisfying customers, and unethical behaviors. By studying the interplay between organizational commitment, behavioral routines, and imagined consequences of behaviors, researchers may obtain more insight into the real nature of the relationship between organizational commitment and its behavioral consequences.

\section{References}

Adler, A., \& Adler, P. (1988). Intense loyalty in organizations: A case study of college athletes. Administrative Science Quarterly, 33, 401417

Ajzen, I. (1991). The theory of planned behavior. Organizational Behavior and Human Decision Processes, 50, 179-211.

Ajzen, I. (2001). Nature and operation of attitudes. Annual Review of Psychology, 52, 27-58.

Ajzen, I., \& Fishbein, M. (1980). Understanding attitudes and predicting social behavior. Upper Saddle River, NJ: Prentice Hall.

Allen, N. J., \& Meyer, J. P. (1990). The measurement and antecedents of affective, continuance, and normative commitment to the organization. Journal of Occupational Psychology, 63, 1-18.

Allen, N. J., \& Meyer, J. P. (1996). Affective, continuance, and normative commitment to the organization. Journal of Vocational Behavior, 49, 252-276.

Angle, H. L., \& Perry, J. L. (1981). An empirical assessment of organizational commitment and organizational effectiveness. Administrative Science Quarterly, 27, 1-14.

Armstrong-Stassen, M. (2006). Determinants of how managers cope with organizational downsizing. Applied Psychology: An International Review, 55(1), 1-26.

Becker, H. S. (1960). Notes on the concept of commitment. American Journal of Sociology, 66, 32-42.

Bentein, K., Vandenberg, R. J., Vandenberghe, C., \& Stinglhamber, F. (2005). The role of change in the relationship between commitment and turnover: A latent growth modeling approach. Journal of Applied Psychology, 90, 468-482.

Bergman, M. E. (2006). The relationship between affective and normative commitment: Review and research agenda. Journal of Organizational Behavior, 27, 645-663.

Bollen, K., \& Lennox, R. (1991). Conventional wisdom on measurement: A structural equation perspective. Psychological Bulletin, 110, 305-314.

Bozeman, D. P., \& Perrewe, P. L. (2001). The effect of item content overlap on Organizational Commitment Questionnaire-turnover cognitions relationships. Journal of Applied Psychology, 86, 161-173.

Brickman, P. (1987). Commitment. In C. B. Wortman \& R. Sorrentino (Eds.), Commitment, conflict, and caring (pp. 1-18). Englewood Cliffs, NJ: Prentice Hall.

Brickman, P., Janoff-Bullman, R., \& Rabinowitz, V. C. (1987). Meaning and value. In C. B. Wortman \& R. Sorrentino (Eds.), Commitment, conflict, and caring (pp. 59-105). Englewood Cliffs, NJ: Prentice Hall.

Brown, R. B. (1996). Organizational commitment: Clarifying the concept and simplifying the existing construct typology. Journal of Vocational Behavior, 49, 230-251.

Buchanan, B. (1974). Building organizational commitment: The socialization of managers in work organizations. Administrative Science Quarterly, 19, 533-546.

Case, J. (2000). Employee theft: The profit killer. Del Mar, CA: John Case \& Associates.

Coffin, B. (2003). Breaking the silence on white collar crime. Risk Management, 50,8

Cohen, A. (1991). Career stage as a moderator of the relationships between organizational commitment and its outcomes: A meta-analysis. Journal of Occupational Psychology, 64, 253-268.
Cohen, A. (2003). Multiple commitments in the workplace: An integrative approach. Mahwah, NJ: Erlbaum.

Cohen, A., \& Freund, A. (2005). A longitudinal analysis of the relationship between multiple commitments and withdrawal cognitions. Scandinavian Journal of Management, 21, 329-351.

Cude, R. L., \& Jablin, F. M. (1992). Retiring from work: The paradoxical impact of organizational commitment. Journal of Managerial Issues, 4, $31-45$.

Dunham, R. B., Grube, J. A., \& Castaneda, M. B. (1994). Organizational commitment: The utility of an integrative definition. Journal of Applied Psychology, 79, 370-380.

Dutton, J. E., Dukerich, J. M., \& Harquail, C. V. (1994). Organizational images and member identification. Administrative Science Quarterly, $39,239-263$.

Eagly, A. H., \& Chaiken, S. (1993). The psychology of attitudes. Orlando, FL: Harcourt.

Edwards, J. R. (2001). Multidimensional constructs in organizational behavior research: An integrative analytical framework. Organizational Research Methods, 4, 144-192.

Edwards, J. R., \& Bagozzi, R. P. (2000). On the nature and the direction of relationships between constructs and measures. Psychological Methods, $5,155-174$

Farrell, D. (1983). Exit, voice, loyalty, and neglect as responses to job dissatisfaction: A multidimensional scaling study. Academy of Management Journal, 26, 596-607.

Fazio, R. H., \& Towles-Schwen, T. (1999). The MODE model of attitudebehavior processes. In S. Chaiken \& Y. Trope (Eds.), Dual-process theories in social psychology (pp. 97-116). New York: Guilford Press.

Fishbein, M., \& Ajzen, I. (1975). Belief, attitude, intention, and behavior: An introduction to theory and research. Reading, MA: Addison-Wesley.

Ford, J. D., Ford, L. W., \& McNamara, R. (2002). Resistance and background conversations of change. Journal of Organization Change Management, 15, 105-121.

Fuller, J. A., Fisher, G. G., Jeffrey, M. S., Spitsmüller, C., Russsell, S. S., \& Smith, P. C. (2003). A lengthy look at the daily grind: Time series analysis of events, mood, stress, and satisfaction. Journal of Applied Psychology, 88, 1019-1033.

Gluckman, M. (1963). Gossip and scandal. Current Anthropology, 4, 307-316.

Gollwitzer, P. M., \& Brandstätter, V. (1997). Implementation intentions and effective goal pursuit. Journal of Personality and Social Psychology, 73, 186-199.

Gollwitzer, P. M., Heckhausen, H., \& Steller, B. (1990). Deliberative and implementational mind-sets: Cognitive tuning toward congruous thoughts and information. Journal of Personality and Social Psychology, 59, 1119-1127.

Greenberg, J. (1990). Employee theft as a reaction to underpayment inequity: The hidden cost of pay cuts. Journal of Applied Psychology, 75, 561-568.

Greenberg, J., \& Baron, A. B. (2003). Behavior in organizations (8th ed.). Upper Saddle River, NJ: Prentice Hall.

Hackett, R. D., Bycio, P., \& Hausdorf, P. A. (1994). Further assessments of Meyer and Allen's (1991) three component model of organizational commitment. Journal of Applied Psychology, 79, 15-23.

Hagedoorn, M., Van Yperen, N. W., Van de Vliert, E., \& Buunk, B. P. (1999). Employees' reactions to problematic events: A circumplex structure of five categories of responses, and the role of job satisfaction. Journal of Organizational Behavior, 20, 309-321.

Hall, D. T., \& Nougaim, K. E. (1968). An examination of Maslow's need hierarchy in an organizational setting. Organizational Behavior and Human Performance, 3, 12-35.

Harrison, D. A., Newman, D. A., \& Roth, P. L. (2006). How important are job attitudes? Meta-analytic comparisons of integrative behavioral out- 
comes and time sequences. Academy of Management Journal, 49, 306325.

Henle, C., Giacalone, R., \& Jurkiewicz, C. (2005). The role of ethical ideology in workplace deviance. Journal of Business Ethics, 56, 219230.

Hirschman, A. O. (1970). Exit, voice, and loyalty: Responses to decline in firms, organizations, and states.. Cambridge, MA: Harvard University Press.

Hollander, E. P. (1971). Principles and methods of social psychology. New York: Oxford University Press.

Jaros, S. J., Jermier, J. M., Koehler, J. W., \& Singigh, T. (1993). Effects of continuance, affective, and moral commitment on the withdrawal process: An evaluation of eight structural equation models. Academy of Management Journal, 36, 951-995.

Kanter, R. M. (1968). Commitment and social organizations: A study of commitment mechanisms. American Sociological Review, 33, 499-517.

Katz, R. (1997). Managing professional careers: The influence of job longevity and group age. In M. L. Tushman \& P. Anderson (Eds.), Managing strategic innovation and change: A collection of readings. Oxford, England: Oxford University Press.

Ko, J.-W., Price, J. L., \& Mueller, C. W. (1997). Assessment of Meyer and Allen's three-component model of organizational commitment in South Korea. Journal of Applied Psychology, 82, 961-973.

Kunda, G. (1992). Engineering culture: Control and commitment in hightech corporation. Philadelphia: Temple University Press

Kuvaas, B. (2006). Work performance, affective commitment, and work motivation: The roles of pay administration and pay level. Journal of Organizational Behavior, 27, 365-385.

Latham, G. P., \& Pinder, C. C. (2005). Work motivation theory and research at the dawn of the twenty-first century. Annual Review of Psychology, 56, 485-516.

Lee, J. A., \& Chulguen, Y. (2005). Factor structure of organizational commitment: Differences between U.S. and South Korean samples. Psychological Reports, 96, 595-602.

Lee, K., Allen, N. J., Meyer, J. P., \& Rhee, K.-Y. (2001). Cross-cultural generalizability of the three-component model of organizational commitment: An application to South Korea. Applied Psychology: An International Review, 50, 596-614.

Lee, T. W., \& Mitchell, T. R. (1994). An alternative approach: The unfolding model of voluntary employee turnover. Academy of Management Journal, 19, 51-89.

Leik, R. K., Owens, T. J., \& Tallman, I. (1999). Interpersonal commitments: The interplay of social networks and individual identities. In J. M. Adams \& W. M. Jones (Eds.), Handbook of interpersonal commitment and relationship stability (pp. 239-256). Dordrecht, the Netherlands: Kluwer Academic/Plenum.

Mathieu, J. E., \& Zajac, D. M. (1990). A review and meta-analysis of the antecedents, correlates, and consequences of organizational commitment. Psychological Bulletin, 108, 171-194.

McGee, G., \& Ford, R. C. (1987). Two (or more?) dimensions of organizational commitment: Reexamination of the Affective and Continuous Commitment Scales. Journal of Applied Psychology, 72, 638-641.

Meyer, J. P., \& Allen, N. J. (1991). A three-component conceptualization of organizational commitment. Human Resource Management Review, $1,61-89$.

Meyer, J. P., \& Allen, N. J. (1997). Commitment in the workplace: Theory, research, and application. London: Sage.

Meyer, J. P., Allen, N. J., \& Gellatly, I. R. (1990). Affective and continuance commitment to the organization: Evaluation of measures and analysis of concurrent and time-lagged relations. Journal of Applied Psychology, 75, 710-720.

Meyer, J. P., Allen, N. J., \& Smith, C. A. (1993). Commitment to organizations and occupations: Extension and test of the three-component conceptualization. Journal of Applied Psychology, 78, 538-551.
Meyer, J. P., Becker, T. E., \& Vandenberghe, C. (2004). Employee commitment and motivation: A conceptual analysis and integrative model. Journal of Applied Psychology, 89, 991-1007.

Meyer, J. P., Becker, T. E., \& Van Dick, R. (2006). Social identities and commitments at work: Toward an integrative model. Journal of Organizational Behavior, 27, 665-683.

Meyer, J. P., \& Herscovitch, L. (2001). Commitment in the workplace: Toward a general model. Human Resource Management Review, 11, 299-326.

Meyer, J. P., Stanley, D. J., Herscovitch, L., \& Topolnytsksy, L. (2002). Affective, continuance, and normative commitment to the organization: A meta-analysis of antecedents, correlates, and consequences. Journal of Vocational Behavior, 61, 20-52.

Mitchell, T. R., Holtom, B. C., Lee, T. W., Sablynski, C. J., \& Erez, M. (2001). Why people stay: Using job embeddedness to predict voluntary turnover. Academy of Management Journal, 44, 1102-1121.

Morgan, R. M., \& Hunt, S. D. (1994). The commitment-trust theory of relationship marketing. Journal of Marketing, 58, 20-38.

Mowday, R. T., Porter, L. W., \& Steers, R. M. (1982). Employeeorganization linkages: The psychology of commitment, absenteeism and turnover. New York: Academic Press.

Mowday, R. T., Steers, R. M., \& Porter, L. W. (1979). The measurement of organizational commitment. Journal of Vocational Behavior, 14, 224-247.

Netemeyer, R. G., Bearden, W. O., \& Sharma, S. (2003). Scaling procedures: Issues and applications. Thousand Oaks, CA: Sage.

Netemeyer, R. G., Johnston, M. W., \& Burton, S. (1990). Analysis of role conflict and role ambiguity in a structural equations framework. Journal of Applied Psychology, 75, 148-157.

Noon, M., \& Delbridge, R. (1993). News from behind my hand: Gossip in organizations. Organization Studies, 14(1), 22-36.

Nunnally, J. C., \& Bernstein, I. H. (1994). Psychometric theory (3rd ed.). New York: McGraw-Hill.

O'Reilly, C. A., \& Chatman, J. (1986). Organizational commitment and psychological attachment: The effects of compliance, identification, and internalization of prosocial behavior. Journal of Applied Psychology, 71, 492-499.

O'Reilly, C. A., Chatman, J., \& Caldwell, D. F. (1991). People and organizational culture: A profile comparison approach to assessing person-organization fit. Academy of Management Journal, 34, 487-516.

Organ, D. W. (1988). Organizational citizenship behavior: The good soldier syndrome. Lexington, MA: D. C. Heath.

Organ, D. W., \& Ryan, K. (1995). A meta-analytic review of attitudinal and dispositional predictors of organizational citizenship behavior. Personnel Psychology, 48, 775-802.

Payne, S. C., \& Webber, S. S. (2006). Effects of service provider attitudes and employment statues on citizenship behaviors and customers' attitudes and loyalty behavior. Journal of Applied Psychology, 91, 365-378.

Perugini, M., \& Bagozzi, R. P. (2004). The distinction between desires and intentions. European Journal of Social Psychology, 34, 69-84.

Pinder, G. C. (1998). Work motivation in organizational behavior. London: Prentice Hall.

Powell, D. M., \& Meyer, J. P. (2004). Side-bet theory and the threecomponent model of organizational commitment. Journal of Vocational Behavior, 65, 157-177.

Randall, D. M., Fedor, D. B., \& Longenecker, C. O. (1990). The behavioral expression of organizational commitment. Journal of Vocational Behavior, 36, 210-224.

Reichers, A. E. (1985). A review and reconceptualization of commitment. Academy of Management Review, 10, 465-476.

Reichers, A. E. (1986). Conflict and organizational commitments. Journal of Applied Psychology, 71, 508-514.

Robinson, S. L., \& Bennett, R. J. (1995). A typology of deviant workplace 
behaviors: A multidimensional scaling study. Academy of Management Journal, 38, 555-572.

Rousseau, D. M. (1995). Promises in action: Psychological contracts in organizations. Newbury Park, CA: Sage.

Rusbult, C. E., \& Zembroth, I. M. (1983). Responses to dissatisfaction in romantic involvements: A multidimensional scaling analysis. Journal of Experimental Social Psychology, 19, 274-293.

Salancik, G. R. (1977). Commitment and the control of organizational behavior and belief. In B. Staw \& G. Salancik (Eds.), New directions in organizational behavior (pp. 51-59). Chicago: St. Clair Press.

Scholl, R. W. (1981). Differentiating organizational commitment from expectancy as a motivating force. Academy of Management Review, 6 , $589-599$.

Shamir, B. (1991). Meaning, self, and motivation in organizations. Organization Studies, 12, 405-424.

Sheldon, M. E. (1971). Investments and involvements as mechanisms producing commitment to the organization. Administrative Science Quarterly, 16, 637-643.

Skarlicki, D. P., \& Folger, R. (1997). Retaliation in the workplace: The roles of distributive, procedural, and interactional justice. Journal of Applied Psychology, 82, 434-443.

Slocum, J., \& Cron, W. L. (1985). Job attitudes and performance during three career stages. Journal of Vocational Behavior, 26, 126-145.

Somers, M. J. (1995). Organizational commitment, turnover, and absenteeism: An examination of direct and interaction effects. Journal of Organizational Behavior, 16, 49-58.

Spreitzer, G. M. (1995). Psychological empowerment in the workplace: Dimensions, measurement, and validation. Academy of Management Journal, 38, 1442-1465.

Stanley, D. J., Meyer, J. P., Topolnytsky, L., \& Herscovitch, L. (1999, May). Affective, continuance and normative commitment: Meta-analyses of interrelations and outcomes. Paper presented at the meeting of the Society for Industrial/Organizational Psychology, Atlanta, GA

Stumpf, S. A., \& Rabinowitz, S. (1981). Career stage as a moderator of performance relationships with facets of job satisfaction and role perceptions. Journal of Vocational Behavior, 18, 202-218.

Sturges, J., Conway, N., Guest, D., \& Liefooghe, A. (2005). Managing the career deal: The psychological contract as a framework for understanding career management, organizational commitment and work behavior. Journal of Organizational Behavior, 26, 821-838.
Super, D. (1957). The psychology of careers. New York: Harper.

Terborg, J. R., Howard, G. S., \& Maxwell, S. E. (1980). Evaluating planned organizational change: A method for assessing alpha, beta, and gamma change. Academy of Management Review, 5, 109-121.

Triandis, H. C. (1977). Interpersonal behavior. Monterey, CA: Brooks/ Cole.

Vandenberg, R. J., \& Self, R. M. (1993). Assessing newcomers' changing commitments to the organization during the first 6 months of work. Journal of Applied Psychology, 78, 557-568.

Van Dyne, L., \& Pierce, J. L. (2004). Psychological ownership and feelings of possession: Three field studies predicting employee attitudes and organizational citizenship behavior. Journal of Organizational Behavior, 25, 439-459.

Van Knippenberg, D., \& Sleebos, E. (2006). Organizational identification versus organizational commitment: Self-definition, social exchange, and job attitudes. Journal of Organizational Behavior, 27, 571-584.

Wanberg, C., \& Kammeyer-Mueller, J. (2000). Predictors and outcomes of proactivity in the socialization process. Journal of Applied Psychology, 85, 373-385.

Wiener, Y. (1982). Commitment in organizations: A normative view. Academy of Management Review, 7, 47-52.

Wiener, Y., \& Vardi, Y. (1980). Relationships between job, organization, and career commitments, and work outcomes: An integrative approach. Organizational Behavior and Human Performance, 26, 81-96.

Wimbush, J. C., \& Dalton, D. R. (1997). Base rate for employee theft: Convergence of multiple methods. Journal of Applied Psychology, 82, $756-763$.

Wood, W., Quinn, J. M., \& Kashy, D. A. (2002). Habits in everyday life: Thought, emotion, and action. Journal of Personality and Social Psychology, 83, 1281-1297.

Wyatt, P. K. (1999). Conceiving couple commitment: Choice, promise, and fulfillment. In J. M. Adams \& W. M. Jones (Eds.), Handbook of interpersonal commitment and relationship stability (pp. 53-71). New York: Kluwer Academic/ Plenum.

Received August 23, 2006 Revision received May 2, 2007 Accepted May 29, 2007 